". . ses-water contains enough salt to be neither a really good conductor of electricity nor a useful insulator, so that in this respect also it is more difficult to work in than is the atmosphere. The salt water also militates against the scientist by being corrosive, and to ensure that experiments shall be conducted with the maximum of difficulty and discomfort, the sea surface is seldom still." Again, "The greater part of the oceans is about three miles deep, so that when apparatus must be lowered to the sea-bed long cables are needed".

Undoubtedly the navies of the world, especially those of the great maritime powers, during and since the Second World War, have contributed much to our knowledge of the sea itself, also of the shape of the deep seafloor; this is an important factor for submarines, now aecustomed to diving much deeper and staying submerged far longer than formerly. Detection of submarines demands an understanding of sound-wave propagation in the sea-water medium, which in turn requires more accurate measurements of temperature and density distribution in the oceans. Of the more peaceful aspects of future ocean investigations are off-shore drilling for new oilfields or important extensions of known continental developments; these projects are proceeding apace to-day and, apart from oil-finding, every hole drilled provides more information of sedimentary accumulations, past and present, forming the continental shelves concerned. In the long run, however, it is the fish in the sea that will take pride of place in future oceanic researches. Increase in world population will compel more attention to the sea as a vast food-producer. As Dr. Gaskell observes: ". . we hunt the fish that Nature provides, just as our ancestors hunted animals for food. We have not yet begun to herd fish or to improve their quality - but one day we shall be forced to farm the seas as we do the land".

H. B. Milner

\title{
THE ROWETT RESEARCH INSTITUTE
}

$\mathrm{T}$ HE report of the Rowett Research Institute for the year $1962-63 *$ is on the same lines as that for the previous year; that is to say, the main section of the report summarizes the numerous papers which have appeared during the year and supplements these summaries with additional unpublished information so as to bring the accounts of the research more nearly up to date. In all, some 150 original papers published by workers in the Institute are referred to, together with references to about 40 papers in preparation and other unpublished observa. tions. These considerable numbers give some idea of the great mass of work proceeding in the Institute, and of the magnitude of the task of presenting a succinct and intelligible account of it within reasonable compass. In addition to this general account of present research within the Institute, the report contains two special contributions on topics deemed to have reached a stage suitable for review.

Both these review articles deal with topies of considerable practical importance in British agriculture. The first, by Dr. T. R. Preston, discusses recent work on highenergy barley diets for livestock feeding. It has been found that, with suitable management, beef cattle may be reared on a diet of 85 per cent of appropriately treated barley and a 15 per cent supplement containing protein, minerals and vitamins. Animals so fed gain weight in the form of lean beef surprisingly rapidly, and it was found possible to bring some dairy-type cattle to a good finish in 10-12 months instead of the usual 18-24 months. The régime, therefore, promises to be economic and profitable and has excited considerable interest among the farming community. It has been introduced into commercial practice, but the resulting meat has encountered some

* Rowett Research Institute. Annual Report on Animal Nutrition and Allied Sciences. Vol. 19. Pp. 83. (Bucksburn, Aberdeen: The Rowett Research Institute, 1963.) $10 s$. criticism on the ground of taste and texture. Dr. Preston's article surveys the scientific background of this topical and somewhat controversial subject.

The other review, by Dr. E. Cresswell, deals with two topics both in connexion with sheep. The first is the problem of the premature dropping of the incisor teeth by certain sheep, more especially mountain breeds on particular diets. The causes of this curious defect have been rather obscure, and an account is given of investigations into the course of abnormal development of the teeth and the means which have been suggested to prevent or minimize the trouble. The second part of this article deals with the problem of providing suitable shelter for sheep during winter storms on mountains or other exposed places. Plans are given of a type of 'stell', which is relatively cheap to construct and which provides shelter for about 100 sheep and at the same time ensures adequate ventilation. Animals so protected are able to pass the winter on the more exposed mountain pastures and do not need to be brought to lower ground for protection from storm and cold.

In a section of the present report giving a brief survey of the past year, reference is made to the fact that in 1963 the Rowett Research Institute celebrates its Golden Jubilee (see Nature, 200, 201, 635; 1963). It was in 1913 that a joint committee of the University of Aberdeen and the North of Scotland College of Agriculture initiated its research programme on the nutrition of farm animals and appointed Dr. John Boyd Orr (now Lord Boyd Orr) to carry out this novel enterprise. The work on animal nutrition has gone on without interruption ever since, apart from dislocations due to two world wars. The contents of this report demonstrate how vigorously the organization then borm has grown, and how it has justified and rewarded the efforts of the pioneers who created it fifty years ago.
W. O. KERMACK

\section{THE MEDICAL RESEARCH COUNCIL}

T HE report of the Medical Research Council for the year 1961-62*, which follows the general plan of this Council's previous reports, reflects, as they did, the trend of medical research as a whole. The volume and wide range of the work being done by the Council's staff and the practical applications of their work are indicated

* Committee of Privy Council for Medical Research. Report of the Medical Research Council for the Year 1961-1962. Pp. viii + 284. (Cmnd. 2075.) (Tondon: H.M.S.O., 1963.) 16s, 6d. net. by the fact that their publications have now become so numerous that it is no longer possible to list them in the report, although details of them can be obtained from the Library of the National Institute for Medical Researeh, Mill Hill, London, N.W.7.

Apart from the usual summaries of researches in progress, which occupies 140 pages of this report, and the details of the personnel employed by the Council, the report includes, as previous reports have also done, a 
section ontitled "Some Aspects of Medical Rosoarch", which is also published separately under the title Current Medical Research (H.M.S.O. 5s. 6d.). This particular section is this year made up of eleven articlos, the range and content of which can be only briefly indicated here.

The first articlo, ontitled "Tho Genetic Code", includes in its scope the work on this subject for which four members of the Council's staff, Dr. M. F. Perutz, Dr. J. C. Kondrew, Dr. F. H. C. Crick and Prof. M. H. F. Wilkins, were, together with Prof. J. D. Watson, awarded Nobel Prizes for 1962 (see Nature, 196, 319, 519; 1962). The socond articlo, ontitlod "Chomieal Mutagens", discusses chemical substances which may produce mutations and their mode of action and their specificity. The third articlo is on coll transformation by tumour virusos, with special reference to the polyoma virus which is boing studied under the direction of Prof. M. G. P. Stoker in tho Council's Exporimontal Virus Rosearch Isaboratory at the University of Glasgow. Next comes an articlo on "Cancer in the Tropics", and this is followed by a discussion of "Rivor Blindness" causod by the parasitic nematodo worm, Onchocerca volvulus, in tropical Africa, an article on the demyelinating diseases, and another on the contral norvous control of the ondocrine glands and the influences oxerted by hormones on tho contral nervous system. 'Then follows a valuable article on the relationship between mental retardation and chemical abnormalities in the body. Two articles discuss tho metabolism of plasma protein and the biosynthesis of sterols, and finally thero is an article on biological engineering, a term of which the author of the article apparently does not fully approve. It refers to the various ways in which engineering tochniquos aro nowadays applied to modicine and the biological sciences, and includes such devices as radiopills and other 'miniaturized' instruments, the whole-body plethysmograph, tho conicycle, which mossures the content of respirable dust and othor aorosols in tho air, the breath-alcohol detector, and the remarkable prostheses which aro now availablo as artificial limbs and other artificial aids, such as plastic hoart valves, ortificial kidneys, heart-lung machines, and aids for the blind and doaf. Tho valuo of this whole section is increased by photographs of a molecular model of deoxyribonucloic acid, of polyoma virus particles and cells transformed by this virus, of a radio-pill and a prosthesis for the arm.

The rest of the report, apart from the deteils it givos of the finance and administration of the Council's work, pays a woll-deservod tribute to the work of Sir Charles Harington, who retired on July 31, 1962, from his post as director of the National Institute for Medical Research, after sorving in that capacity for twonty years (see Nature, 195,$228 ; 1962$ ). During this period the Institute's scientific work was greatly extended, the number of its staff incroasod from 35 to 125 and tho Council enjoyed the great benefit of Sir Charles's advice on both research and policy. Everyone interested in the Council's work will bo glad to know that Sir Charles will still be available as consultant adviser to the Council's seerotary.

In another section on the Council's Advisory Boards it is oxplainod that knowledge and resoarch have become so complex that tho Council, which has always boon averse to "any arrangement which implies that ono singlo body should bostrido tho field of clinical or any othor type of research", has devised a systom of Boards which are, in effect, sub-councils. The first of these, the Clinical Research Board, was appointed in 1953. Afterwards, a Tropical Medicine Research Board was established, and in 1962 a Biological Research Awards Committco was created. By means of these Advisory Boards, which enable the Couneil to bonefit from the advice of many experienced specialists, the Council is able to decontralize effectivoly the ovor-increasing complexity of its work.

No one can doubt, after roading theso woll-written and closely reasoned pages, that here we have an organization of scientists working together and directing their own work free from Governmental control, which ensures, as no other kind of organization can do, that all tho sciencos, whother they are primarily medical or not, are effectively integrated together for the benofit of man and other animals. Long may it continue to produco tho remarkable results that, yoar by year, are recordod in its reports.
G. LAPAGE

\section{THE LIQUID STATE}

$\mathrm{T}$ HE Institute of Physics and the Physical Socioty hold a conforoneo on "Tho Liquid State" at the Imperial College of Science and Technology, London, during Septomber 9-13.

Tho study of the structure and properties of liquids, like many branches of classical physies, is a subject in which real progress is now slow and irregular. There was a burst of activity aftor tho Socond World War in which the implications of the integral equations for the distribution functions of Yvon, Kirkwood, Born and Green were studied and in which the limitations of Kirkwood's 'superposition' approximation came to bo appreciated. 'This was followed by an advance in 'experiment' when, in the 1950 's, computers woro used to caleulato the pressure and rato of approach to equilibrium of systems of simplo moloculos by, for oxample, the solution of the equations of motion of a small represontative assombly. This work gavo an impotus to the study of simple models, and the past two years have soon the dovelopment of at least two new sets of integral equations and for ono of thom, the oquations of Porcus and Yevick, their exact solution in closed form for a systom of hard spheres. Meanwhile, there have been substantial advancos in the theory of transport proporties, although there is still argument about the legitimacy of some of the steps that are necessary to relate these properties to tho intermolocular forces. Thoso dovelopments were reflected in many of the 68 papers presentod at this conference, and a selection of these aro described briefly in this report.
Tho first day was a discussion of methods of determining structure. In the oponing roviow, Dr. I'. A. Egolstaff (Atomic Energy Research Establishment, Harwell) emphasized the powor of tho mothod of neutron-scattering. Thermal neutrons can show shifts of both wavo-voctor and onergy whon scattered by liquids and so can be used to supplemont tho information from X-ray diffraction and light-scattering experiments. Dr. S. J. Cocking (Atomic Energy Research Establishment, Harwell) illustrated this in outlining his investigations of the motion of atoms in molten lead. Dr. J. A. Flliot, Prof. H. E. Hall and Dr. J. M. Williams (University of Manchester) described the use of tho Mössbauer effect for the study of diffusion in glycerol, and Dr. J, G. Powles (Queon Mary Collogo, London) has used nuclear magnetic resonance to examine rotational rolaxation.

Prof. J. D. Bernal and Miss S. V. King (Birkbock College, London) reported further experimental studies of random closo-packed arrays of stool balls, and suggested that such arrays often showed long ordorod linos of particles. This point was taken up the next day when Dr. B. J. Aldor (Livormore, California) discussed his computer calculations on the transition from ordored to fluid phaso in a two-dimensional array of hard disks. $\mathrm{H}_{\Theta}$ suggested that molting might start when lines of molecules could slide past each other. Hithorto Bernal's studios havo had littlo contact with more conventional theories of liquids, but an attompt to bridge this gap was made by Prof. R. Fürth (Birkbeck College, Tondon). 